\title{
Styrene Oxide
}

National Cancer Institute

\section{Source}

National Cancer Institute. Styrene Oxide. NCI Thesaurus. Code C44447.

A synthetic, colorless liquid that is very soluble in water. Styrene oxide is used as a chemical intermediate in the production of styrene glycol and its derivatives, cosmetics, surface coatings and other chemicals (agricultural and biological). It is also used as a reactive diluent for epoxy resins and in cross-linked polyesters and polyurethanes. Humans in the general population may be exposed to styrene oxide by contact with contaminated air or water. It is reasonably anticipated to be a human carcinogen. $(\mathrm{NCl05})$ 